\title{
DETOURS ON THE ROAD TO MATURITY: A VIEW OF THE LEGAL CONCEPTION OF GROWING UP AND LETTING GO
}

\author{
F. RAYMOND MARKS*
}

\section{INTRODUCTION}

Adolescence-in a social sense-is largely a twentieth century creation. ${ }^{1}$ In earlier times, the adolescent performed adult economic roles ${ }^{2}$ and was allowed at a younger age to leave home and otherwise to assume reponsibility for his own life. Today, however, the adolescent's position in the family is more anomalous and troublesome. ${ }^{3}$ Although able to work, engage in mature sexual relations, and make moral choices, he is denied full adult status and recognition in his family, the marketplace, and society at large. This period of his life has become one of prolonged-and usually less happy-economic and psychological dependence, which is both reflected in and reinforced by contemporary law. ${ }^{4}$

Some recognition has recently been accorded the adolescent's distinctive interests vis-a-vis his community ${ }^{5}$ and the state; ${ }^{6}$ but except for his right to be supported, maintained, and protected and his right to hold property, ${ }^{7}$ his

\footnotetext{
* Counsel and Research Attorney, Childhood and Government Project, University of California, Berkeley. The author is indebted to Sarah Leverett, Abigail English, Lisa Salkovitz, and Sandra Bressler, students at the School of Law, University of California, Berkeley, for their research assistance in the preparation of this article; to Stanley Katz, University of Chicago, Marvin Lazerson, University of British Columbia, Anselm Strauss, University of California, San Francisco; and to Charles Benson, Robert H. Mnookin, and Will Riggan, Childhood and Government Project, University of California, Berkeley, who have critically reviewed its earlier drafts.

1. "Adolescence" is a comparatively recent operational term. It has been intimated that the term was not widely used prior to the publication of G. Hall, Adolescence (1904). See also O. \& M. Handin, Facing Life 152-53 (1971); see J. Demos, A Little Commonwealth 145 (1970); Skolnick, The Limits of Childhood: Conceptions of Child Dezelopment and Social Context, 39 LAW \& Contemp. Prob. no. 3, at 38 (1975).

2. See Stern, Smith, \& Doolittle, How Children Used to Work, 39 Law \& Contemp. Prob. no. 3 at $93(1975)$.

3. See, e.g., O. \& M. Handlin, supra note 1 passim. See also J. Demos, supra note 1, at 185-87.

4. There are, of course, exceptions to this statement-most notably, perhaps, in the area of medical treatment. See discussion at notes 61-63 infra and accompanying text.

5. E.g., a child, independent of his parents, can sue and recover damages from those who interfere with his person or personality interests. See F. HARPER, A Treatise on the Law of Torts 623-24 (1933); W. Prosser, Torts 885 (3d ed. 1964); $c f$. J. Fleming, The Law of Torts 253-54 (1965).

6. See, e.g., Tinker v. Des Moines Independent Community School, 393 U.S. 503 (1969) and Buckholz v. Leveille, 37 Mich. App. 166, 194 N.W.2d 427 (1972), which are discussed at notes 70 \& 71 infra and accompanying text.

7. See Pound, Individual Interests in the Domestic Relations, 14 MicH. L. REv. 177 (1916).
} 
distinctive interests vis-à-vis his parents have not been comparably dignified. He still is governed, for the most part, by the same "law of infancy" that is applied to his younger siblings: like the seven-year-old, the seventeen-year-old living at home for many legal purposes remains simply "an unemancipated minor." Thus, like the younger child, the adolescent is subject to the exercise of parental authority-to the preemption of choice, ${ }^{8}$ or at least to parental veto of his exercise of the power of choice. Indeed, legal sanctions may attend his noncompliance with these parental decisions or his refusal to accept the consequent lawful discipline that his parents may seek to administer-not to mention the many less heroic means by which parents customarily assert and enforce their control over children, from physical punishment and economic pressure $^{9}$ to the withdrawal of approval and affection.

That there is conflict between the legal rules governing the adolescent and the realities of his world is evident. Kenneth Keniston has noted that the postponement of the assumption of adult roles may extend well beyond the legal age of majority-into the twenties and thirties. ${ }^{10}$ The widely-noted symptoms of youthful tensions and alienation accordingly may reflect an attempt by the adolescent to reclaim some responsibility for his own life on his own terms, including the assumption of risk for his own failure or drift. A quest for new adult roles may also be involved-roles validated by the adolescent himself, and not by others (including parents) who have been "preparing" him. Thus viewed, the adolescent "rebellion" can be understood as a natural consequence of the artificial and external extension of subordinated status well after the biological being craves for autonomy, for distinctness of personality.

In order to clarify this perspective, this article presents an historical examination of how law has shaped, constrained, and reflected the social role of youth in America. It is divided into three parts. Part I surveys the historical antecedents that led in the early nineteenth century to a diminution of social control over the life of the adolescent. Part II then covers the period from roughly 1870 to 1920 , in which there is seen a new and different kind of assertion of control over youth. And part III finally views the contemporary scene, assessing the impact of prolonged adolescent dependence and speculating as to the possible restoration to the adolescent of some greater measure of legal autonomy.

8. See Wisconsin v. Yoder, 406 U.S. 205 (1972), in which the Court seems to assume the propriety of parental choice of an adolescent's religion.

9. See, e.g., Roe v. Doe, 29 N.Y.2d 188, 262 N.E.2d 567, 324 N.Y.S.2d 71 (1971), which is discussed at note 50 infra and accompanying text. Child neglect sanctions, however, apparently limit the scope of this parental weapon, at least in the case of a younger child.

10. See K. Keniston, The Uncommitted: Alienated Youth in American Society 196-200 (1965); cf. E. ERIKSon, Identity, Youth ANd Crisis 128-35 (1968). 


\section{Children in Relation to Their Families AND THE COMMUNITY (1607-1870)}

Until late in the nineteenth century, the economic needs of both the community and families in America dictated the early assumption by children of adult economic roles. If children worked on the family farm or in the family trade, they usually learned these roles well before their teens. ${ }^{11}$ If they left the family to enter apprenticeship or service-or later in time to enter factories or to make their own way-this generally occurred in their early teens. ${ }^{12}$

In the course of this first 250-year period of the American experience, the definition and duration of childhood passed through two distinctly different phases. In colonial times, children cast in adult economic roles were constrained by rigid social controls. They worked not for their own account, but for the account of their parents or their masters, to whose control they were subject until they reached the age of twenty-one years. This control was imposed not only by family function, but by the community as well, and was reinforced by religious values. ${ }^{13}$ In the early years of the republic, however, the rigidity of this pattern was relaxed, and assumption of adult social roles came more closely to approximate assumption of adult economic roles, as a concept of early emancipation began to emerge. Children more and more came to be regarded as responsible for themselves at an earlier age, as they worked for their own account or left home to strike out on their own.

The adolescent in the colonial period frequently lived outside of his own family home, but he invariably lived within some family-most frequently that of his master. ${ }^{14}$ The adolescent was held accountable to his parents or his master for his economic productivity. Parents and masters correlatively were required to see to it that he worked, that he was maintained (so as not to become a public charge) and that his behavior was controlled (so that he did not become a public nuisance). ${ }^{15}$ Where a child was orphaned or abandoned

11. See 1 Children and Youth in America (1600-1865), at 103-22 (R. Bremner ed. 1970); J. Demos, supra note 1, at 145 et seq.; O. \& M. HANDLIN, supra note 1 chs. 2 \& 3.

12. See J. Demos, supra note 1, at 140; J. Hawes, Children in Urban Society 14 (1971).

13. See J. Demos, supra note 1 chs. 6 (esp. 100-04) \& 7 (esp. 111-13).

14. A town law of 1636 prohibited single persons from living outside of families approved by the town selectmen. See The Compact With the Charter and Laws of New Plymouth 156 (W. Brigham ed. 1836).

15. See, e.g., Law for Training of Children and Servants in the Home (1642), in 2 MassachusetTS BAy ReCoRds 8-9 (1853). Complementary laws, addressed to the child, enjoined obedience to parents and masters. See, e.g., 1 Ancient Town Records of Connecticut 88-89 (F. Dexler ed. 1917); I Public Records of Colony of Connecticut 78 (J. Tranbull ed. 1850); 3 Massachusetts BAy Records 101, 355 (1854). These "stubborn children" laws were the historical antecedents of the P.I.N.S. (persons in need of supervision) and M.I.N.S. (minors in need of supervision) jurisdiction of the modern juvenile court. 
or his parents failed to support him, town selectmen, acting as parental surrogates, indentured the child into the service and control of a master. ${ }^{16}$

There was little or no pressure in the colonial period to give the adolescent his "own time." He occupied a subordinate status until his twenties. Unlike the present, however, it was not a subordinate status within a nuclear family, but rather one within a working unit, within a unit of social control, and within the community-at-large as a contributing member of society.

Beginning in the late eighteenth century, however, the law began to impose limitations on parental exploitation of a child's labor outside the home. Thus, in 1793-in Respublica v. Kepple $e^{17}$ - the Pennsylvania Supreme Court held that there were limits to the purposes for which parents could bind out a child: they could bind him out to learn a trade, but not as a servant. Before Kepple, parents presumably could assign to another both their rights to the services of a child and their obligation to support him, without particular reference to the interests of the child. Kepple, however, held that parental authority was limited by what the community perceived the parental function to be-in this particular instance, the preparation of the child for full assumption of some economic role, not the mere facilitation of his entry into the marketplace nor the simple offsetting of a parental obligation of support. Parents could have the benefit of the child's services or relief from their obligations of support, but only as an incident of preparing him for later life.

As the economy expanded and as options increased, the place of the child in the economy came less and less to be associated with the continuity of family life. By 1800, the laws that prohibited children from living apart from families were either repealed or ignored. Children, including some who were very young (eight to twelve years of age) went away to work in factories, where they lived in dormitories or boardinghouses. ${ }^{18}$ Sometimes the factories assumed a master-like role and undertook to oversee the education and moral guidance of their young workers, thus following the earlier conventions relating to apprenticeships. This paternalism, whether voluntary or required by

16. See, e.g., Acts and Laws of His Majesties Colony of Connecticut in New England 95-96 (1715); 2 Massachusetts Bay Records 180 (1646); Records of the Colony of New Plymouth: Laws 1623-1682, at 38 (D. Pulsifer ed. 1861); 2 Virginia Statutes at Large 298 (1672); 1 Virginia Statutes at Large 336-37 (1646). See generally l Children and Youth in AMERICA, supra note 11 , at 65-68.

17. $1 \mathrm{~Pa} .233$ (Sup. Ct. 1793).

18. Two systems were developed for the recruitment of children to work in the factories. Samuel Slater followed the English plan of employing entire families, and this family system was largely employed in the smaller factories in Rhode Island, Connecticut, and southern Massachusetts. The alternative, first employed in the textile mill in Waltham, Massachusetts, was the boardinghouse system, where some children, mostly young girls, worked in the factory, while their parents continued to live on the farm. This latter system became more common after the 1820's in large factories employing older girls in Lowell and Lawrence, Massachusetts, in Dover, Manchester, Exeter, and Portsmouth, New Hampshire, and in Maine. See 1 Children and Youth in AMERICA, supra note 11 , at $145-46$. 
law, ${ }^{19}$ nevertheless was far different from the "child raising" formerly seen in the family setting.

Tocqueville, writing about the American family in the 1830's, described the shift in parental and societal attitudes that accompanied this development: ${ }^{20}$

It has been universally remarked in our time the several members of a family stand upon an entirely new footing towards each other; that the distance which formerly separated a father from his sons has been lessened; and that paternal authority, if not destroyed, is at least impaired. . .

$[A] s$ soon as the young American approaches manhood, the ties of filial obedience are relaxed day by day; master of his thoughts, he is soon master of his conduct. In America there is, strictly speaking, no adolescence: at the close of boyhood the man appears and begins to trace out his own path.

It would be an error to suppose that this is preceded by a domestic struggle in which the son has obtained by a sort of moral violence the liberty that his father refused him. The same habits, the same principles, which impel the one to assert his independence predispose the other to consider the use of that independence as an incontestable right. The former does not exhibit any of those rancorous or irregular passions which disturb men long after they have shaken off an established authority; the latter feels none of that bitter and angry regret which is apt to survive a bygone power. The father foresees the limits of his authority long beforehand, and when the time arrives, he surrenders it without a struggle; the son looks forward to the exact period at which he will be his own master, and he enters upon his freedom without precipitation and without effort, as a possession which is his own and which no one seeks to wrest from him.

At this time, the legal doctrine of emancipation began to emerge. ${ }^{21}$ In its narrowest, its first, and perhaps its principal sense, emancipation described the termination of the child's economic servitude to his father ${ }^{22}$ In this sense, emancipation released to the child, for the balance of his minority, the benefits of his own services, including his wages; ${ }^{23}$ and correlatively, it released the parent from his obligation to support the child. ${ }^{24}$ The courts, however,

19. For example, Connecticut promulgated the first such law in the country which required that children employed in factories, "whether bound by indenture, by parol agreement or in any other manner, be taught to read and write," and that "due attention be paid to the preservation of their morals ...." Public Statutes of Connecticut, October 1808-May 1819, ch. 2, at 117-18 (May Session 1813).

20. 2 A. de Tocqueville, Democracy in America 192-93 (1946).

21. The "emancipation" cases arising at this time are not numerous, and they reflect not direct disputes between parents and children, but rather disputes between creditors and parents or employers and parents in which children were only coincidentally involved. Essentially, emancipation requires either explicit parental consent or parental acquiescence in the child's assumption of an autonomous role. And these cases are significant in that they signal a shifting community attitude towards this practice.

22. Early emancipation cases characterized childhood as a period of economic "bondage." See, e.g., Dunlap v. Dunlap, 84 N.H. 352, 50 A. 905 (1930), in which earlier New Hampshire cases are reviewed and discussed.

23. Id. See also Hall v. Hall, 44 N.H. 293 (1862), and Moses Chase v. Henry Smith, 5 Vt. 556 (1833), in which it was observed that a father can give his son "his time."

24. See, e.g., Angel v. McLellan, 16 Mass. 27 (1819). 
did not always find a perfect approximation of these reciprocal releases. A status of partial emancipation was also legally recognized-although the child might be out of the home supporting himself, the road back was not barred. ${ }^{25}$ Whether the child's venture into the world was permanent or temporary -subject to recall or exigency-depended on the circumstances of each case.

The age of maturity in the early and mid-nineteenth century was a flexible concept. Courts were reluctant to impose a rigid standard on parents, but rather permitted the father to decide, without community interference, when his child was ready for independence. Thus, the Vermont Supreme Court, in a suit by a fourteen-year-old boy to secure his own wages free from the claims of his father's creditors, held that the father's prior acts resulting in the boy's emancipation could not be judicially questioned on the basis of the creditors' contention that the boy "was too young." 26 There was no law and no pervasive policy prohibiting early emancipation; parents were not discouraged from "letting go." And just as important, parents thereafter were not ordinarily charged with responsibility for their child's delinquency or destitution-their function and their responsibility were discharged when the child was allowed to leave.

Judicial inferences about parental intent to emancipate often varied with the procedural context of the case and a sense of social comfort with the results. Thus, if creditors were seeking to attack the wages of a child for the debts of his father, a court might locate some agreement or find some facts otherwise to support an inference that the child was entitled to his own wages. ${ }^{27}$ But if the child lived at home, although earning his own wages, paying his own board, and fully autonomous in other respects as well-as not infrequently was the case-an inference of emancipation was not so readily drawn. ${ }^{28}$

Emancipation by voluntary parental action could occur through other than release of the child's wages. Consent to marriage and consent to entry into military service sufficed, as did cruelty and abandonment-presumably also voluntary acts. ${ }^{29}$ Parental poverty or hospitalization or death-involuntary acts -could force emancipation as well. ${ }^{30}$

25. Cf. Inhabitants of Searsmont v. Inhabitants of Thorndike, 77 Me. 504, 1 A. 448 (1885).

26. Bray v. Wheeler, 29 Vt. 514 (1857). See also Corey v. Corey, 36 Mass (19 Pick.) 29 (1837), in which the court did not question the power of the father to emancipate a son as young as thirteen years of age.

27. See, e.g., Benziger v. Miller, 50 Ala. 206, 209 (1874), in which the court observed that " $[\mathrm{t}] \mathrm{he}$ law does not make a man's child his slave, or servant, at the instance of his creditors or other persons. His right to the profit of the child's service is in consideration of his duty to provide for the child." See generally Inhabitants of Searsmont v. Inhabitants of Thorndike, 77 Me. 504, 1 A. 448 (1885).

28. See, e.g., Chase v. Elkins, 2 Vt. 290 (1829).

29. See, e.g., The Etna, I Ware 474 (Me. 1838).

30. See, e.g., Jenness v. Emerson, 15 N.H. 486 (1844). 
Children might also leave home, of course, simply or rebelliously, without parental consent. After the runaway apprentice laws ceased to be enforced, such children, particularly adolescents, were not returned to their families. The paramount legal question perceived rather was whether the circumstances relieved the father of his obligation to support the child. In the case of a son at least, a court would incline to assimilate the matter to full emancipation. Thus, one court observed: "To permit a minor, at his election, to depart from his parent's house, with power to charge that parent with his support, would tend to the destruction of all parental authority, and invert the order of family government." ${ }^{31}$ And another court elaborated: ${ }^{32}$

[W] hen a child leaves his parent's house voluntarily for the purpose of seeking his fortune in the world or to avoid the discipline and restraint so necessary for the due regulation of families, he carries with him no credit; and the parent is under no obligation to pay for his support.

[Should] a refractory or vicious son leave his father's house without being exposed to want . . . the motive for submitting to authority might be materially impaired, and a great dimunition of parental influence might ensue. One of the greatest restraints upon the bad passions and vicious propensities would be removed, if young persons should feel that they could flee their parent's presence without suffering in any of the essentials of life.

Nor were parents charged with an obligation to pursue absconding children. While parents could not abandon or desert very young children with impunity, ${ }^{33}$ the "neglected" or "independent" children concepts later articulated in juvenile court acts were applied to neither adolescents nor their parents.

The law did not, however, encourage the complete emancipation of daughters, even though this, too, might be seen as economically useful. "Letting go" of a daughter conflicted with the prevailing social attitudes towards the sheltering and protection of women. Where a thirteen-year-old son had voluntarily left home for three years to work elsewhere for his own account, a court had little difficulty in finding that he had permanently left. ${ }^{34}$ On the other hand, however, if a daughter had done the same without parental consent, the court would likely have found that the father had not been released of his obligation of support, even though she had a right to her own earnings. ${ }^{35}$ The courts seemed to be saying that a daughter might leave per-

31. Weeks v. Merrow, 40 Me. 151,152 (1855).

32. Angel v. McClellan, 16 Mass. 27, 31 (1819).

33. See, e.g., Compiled Laws of Michigan (1857) ch. $180, \$ 5741$ (enacted in 1846), making it a crime for parents to abandon a child under six years of age.

34. See Angel v. McClellan, 16 Mass. 27 (1819).

35. See, e.g., Porter v. Powell, 79 Iowa 151, 44 N.W. 295 (1890); Inhabitants of Searsmont v. Inhabitants of Thorndike, 77 Me. 504, 1 A. 448 (1885); Inhabitants of Bangor v. Inhabitants of Readfield, 32 Me. 60 (1850); Inhabitants of Clinton v. Inhabitants of York, 26 Me. 167 (1846). 
manently before her majority only for marriage - an event that frequently occurred when she was as young as thirteen or fourteen years of age. ${ }^{36}$

In summary, prior to the social reform movement that developed in the latter part of the nineteenth century, the maturation of children in this country was legally recognized at ages much younger than today. In the colonial period, children were subject to strict parental control, but they were expected to and did work at adult tasks-albeit for the account of others and without any power to negotiate terms. By the early nineteenth century, however, a trend toward emancipation developed, and the adolescent came to be recognized as having the legal capacity to bargain for full autonomy, while parents were concomitantly relieved of control and support responsibilities.

\section{The Transition: A Major Shift in Parental, Community and Legal Attitudes About Coming of Age (1870 to 1920)}

Around 1870, parentạl, community, and legal attitudes towards both the method of preparing children for adult roles and the timing of their departure from home began to change-as did, indeed, the central definition of childhood itself. The social upheaval that accompanied the burgeoning industrialization of the time gave rise to profound changes in the way in which children were seen in reference to both their parents and the world. Toleration-even tacit encouragement-of parental release gave way to insistence on parental retention and further preparation for adult roles during prolonged childhood period.

Industrialism had brought new uncertainty, alienation, and dislocation that translated directly into an almost instinctive need to hold on to children longer. The Handlins, in Facing Life, observed (speaking of the period commencing around 1870$):{ }^{37}$

Now [with the coming of the Industrial Revolution] external dangers and internal readjustments also threatened the stability of the family. The aftereffects of war, the gigantic fortunes in the hands of new men, the alteration of neighborly responsibilities, and the weakening of supernatural religious beliefs, as well as the growth of factory and city, deprived parents of the guidance of reliable standards and persuaded them to keep their young sheltered longer than formerly. Furthermore, fathers and mothers were less certain than before about the adult roles for which they prepared their children.

36. See, e.g., Ward v. Laverty, 19 Neb. 429, 27 N.W. 393 (1886). See also Parton v. Hervey, 67 Mass. 119 (1854), in which the marriage of a thirteen-year-old girl-even without the usually required parental consent-was held valid and binding.

37. O. \& M. Handlin, supra note 1 , at 150. 
Thus, as the nature and extent of the parental role in preparing children for adulthood became more questionable, assertion of an expanded and prolonged role-paradoxically-became more pronounced. ${ }^{38}$

As parents were caught up in the process of industrialization, they came to sense a hopelessness about themselves-a loss of contact with the land and with their own craft. Not only was life uncertain-which it always would be -but one's sense of location in life or relation to it became uncertain. Life in the city, life chained to a machine loomed threateningly. The frontier was disappearing, and there seemed to be no way out-except the children, who rapidly and suddenly were perceived as the source of salvation. ${ }^{39}$ Although Karl Marx had observed that religion was the opiate of the masses, holding forth to industrial workers the promise of reward in the future as a means of reconciling them to the seeming hopelessness of the present, in the American context, the opiate seemed to lie elsewhere. Here, the secularization of life had diminished religion, and children instead became the means of an earthly redemption. Why wait for eternity when one could hope to obtain a reward-or some validation of one's life-here on earth? If parents could not escape the system, their children could if-and only if-they were prepared.

This new perspective appeared to reallocate intergenerational roles and responsibilities. Nobody was to take direct responsibility for himself; nobody was to live his own life. Parents were to validate their children, and children were to validate their parents; childhood was to be a time to be prepared for adulthood, and adulthood was to be a time to prepare children. The nuclear family became the darling of such institutions as the school and the juvenile court, for which it served as a base line and, in a sense, as a model. ${ }^{40}$

Legislative implementation of three major institutional changes-the juvenile court system, the prohibition of child labor, and compulsory education-seems to confirm this analysis. ${ }^{41}$ In all three, external support of the family as the ideal way additionally to prepare children to face life was seen as basic: bolster the family, leave even the delinquent child in the family-where possible, shield the child from adult roles and responsibilities, and formally educate him, and upward movement could be expected. ${ }^{42}$

38. Another paradox may be seen in the fact that the protracted period of preparation resulted in children being overprepared for jobs that no longer required the degree of skill they did before the industrial revolution. The new myth of success and hope of escape from the system, however, long hid this. And there is a further possibility that the myth was nurtured by others than parents: employers-users of labor-could surely benefit from the socialized obedience of workers that had been reinforced by the prolongation of the period of dependence, even if it produced no other marketable skill.

39. See B. Wishy, The Child and the Republic passim (1968).

40. See W. O’Neil, Divorce in the Progressive Era (1967).

41. For historical development, see generally 2 ChILDREN AND Youth IN AMERICA, supra note 11 .

42. The growing number of immigrants who lived in the tenements of the city and worked in its sweat shops and factories also conduced to this change. Immigrant parents were seen to need 
Thus, the juvenile court movement not only sought an end to holding youthful offenders to adult standards of accountability, but also attempted to model institutional care on the family. The central theme of its approach to delinquency was that the proper place for the adolescent was the fit, natural home-either one in fact or a state-supplied alternative model. Just as important, the jurisdiction of the juvenile court over neglected and dependent children rested on the same assumption: potential delinquency was perceived when a home was found to be unfit or parents too lax in controlling their children.

Child labor legislation reflects concerns similar to those that lay behind the juvenile court movement-concern about the preservation of the family, concern about the impact of an urbanized industrial life on children, and concern about the social effects of underpreparation. This legislation was directed at removing younger children and adolescents from the marketplace back to the home. As was the case in the juvenile court movement, the underlying purpose of child labor laws was child welfare, but here the goal was more sharply and explicitly defined: escape from exploitation by the system. The legislative explanations nicely complemented the parent's own dreams: childhood was idealized as a time for preparation and hence for assuring success in later life.

Prior to the industrial revolution, child labor legislation had not been directed at barring children absolutely from the work force; rather, it had been principally concerned that all working children would also be afforded an opportunity to obtain an education. ${ }^{43}$ By 1880 , however, the emphasis had shifted decidedly. Focus was fixed on the children of the urban poor, who were seen as defenseless against the threat of economic exploitation and vulnerable to the risk of being trapped in the lower precincts of a mechanistic, impersonal system. One reformer described the circle of deprivation: "poverty of parents, premature employment, and children's poverty in maturity." 44

Most of the early arguments against child labor assumed the availability of an alternative institution, the public school-children should be in school and not in the factory-which, again, supports the thesis that childhood was viewed as a time for preparation. But economic arguments were mustered too: cheap child labor would depress factory wages and older workers would be driven out of the marketplace; moreover, as labor was cheapened, children would be forced to work to contribute to family support-and the cycle would thus be reinforced and perpetuated.

\footnotetext{
aid in socializing their children into the way of life in the new country, in finding the "right" way to raise them. This view of immigrant needs was particularly instrumental in the process of involving the state more extensively and actively in a parenting role-not only in guiding and encouraging natural parents, but frequently in supplementing or even substituting for their efforts as well. See generally A. Platt, The Child Savers (1969).

43. See note 2 supra and accompanying text.

44. 2 ChILdReN ANd Youth in AMERICA, supra note $11 \mathrm{pt}$. 5, at 601 .
} 
With the passage of child labor legislation, the prolongation of childhood was facilitated. Henceforward, adult economic roles would be out of the reach of adolescents, and adolescence would be more clearly defined as a formal and dependent period of life.

Compulsory education laws filled out the picture. Even more explicitly than neglected child laws, they sought to specify exactly where the child-now precluded from the regular work force-properly should be; they sought to designate the school as the social institution other than the family that would formally prepare him for life. The child would be nurtured by the family, but he would be socialized by the school. ${ }^{45}$ Public policy required no less. ${ }^{46}$ Thus, by 1890 , compulsory education laws had been adopted in twenty-nine states, and by 1918 , they were universal.

In summary, by the early twentieth century, the notion that a child upon reaching puberty could assume a status independent of his parents had virtually disappeared. The state compelled the extension of childhood-enjoining longer supervision, more protracted education, and the postponed assumption of adult economic roles. Social developments accompanying the industrial revolution had obliterated the fact that the adolescent was formerly regarded as ready for life. The structure of childhood had been changed in response to a mixture of high purpose, hope, fear, and despair. The myth had emerged that a new incremental preparatory period was necessary for success in later life. And, more important, active state participation in this preparation had been legitimated, and an at least implicit standard about the "right" way to raise children had been formulated. The natural family perdured as the basic social unit, but it was supported by outside institutions and burdened by formal expectations, reflecting new public policy considerations.

\section{Children in the Family Today: the Harvest of Prolonged DePendence and the Seeds of New Discontent}

Despite some recent countercurrents, the central legal relationship between the adolescent and his parents has not changed substantially since 1920 .

45. See id. at pt. 6. See also L. Cremin, The Transformation of the School 58-59 (1961).

46. See, e.g., State v. Bailey, 157 Ind. 324, 329-30, 61 N.E. 730 (1901), in which the court, upholding the constitutionality of a compulsory education statute, observed:

The natural rights of a parent to the custody and control of his infant child are subordinate to the State and may be restricted and regulated by municipal laws. One of the most important natural duties of the parent is his obligation to educate his child and this duty he owes not to the child only, but to the commonwealth. If he neglects to perform it, or willfully refuses to do so he may be coerced by law to execute such a civil obligation. The welfare of the child, and the best interests of society require that the State shall exert its sovereign authority to secure to the child the opportunity to acquire an education. 
Thus, if his parents do not acquiesce, they may either prevent his departure from or compel his return home, invoking-if they wish-the aid of the state $^{47}$ under statutes ${ }^{48}$ that are strongly reminiscent of those that were found in runaway apprentice and servant laws and fugitive slave laws. But such heroic steps may be unnecessary, as parents have at their disposal other more prosaic means of bending the adolescent to their will. They can, for example, within limits, threaten to-and actually-withdraw or reduce their economic support of a fractious child. ${ }^{49}$ This can be powerfully coercive, particularly for the adolescent under the compulsory school-attendance age. Prevented from entering the job market-either directly, by the child labor laws, or indirectly, by rising credentialism, which seems to require a high school diploma even for unskilled jobs-the adolescent may be forced to obey his parents simply because he has no practical alternative.

Short of leaving home or forcing a direct legal test of parental authority, however, children in most families do bargain with their parents and do test or avoid-either overtly or covertly - the impact of total parental choice. The adolescent does have some irreducible biological and psychological autonomy, regardless of his legal status or privacy interests vis-a-vis their parents. He may, therefore, be able to "leave" home by means other than actual physical departure. It is in this area that the impact of legal policy and the dissonances that it may have created will primarily have to be confronted. Has the myth of new family function-the readying of the young to succeed where their parents had not succeeded-worked? Has there been an acceptance by the children of this "other directedness,"

Through the 1950's, the children of the affluent and those who had attained or were aspiring to middle class status apparently accepted the period of prolonged preparation for adulthood and its underlying rationale. Whatever tensions this may have generated did not erupt into widespread intrafamilial conflict. Erik Erikson has suggested, however, that what was not apparent on the surface may have been boiling beneath: parents came to disbelieve the myth; they had been promised autonomy (and happiness) as a result of their preparation, and it had not come. Still, they perpetuated the

47. See Note, Ungovernability: The Unjustifiable Jurisdiction, 83 Y ALE L.J. 1383, 1385 n. 21 (1974), in which it is stated that 59 per cent of New York's supervision cases are commenced by parental complaint to authorities.

48. Most states specifically provide in their juvenile court laws for the return of runaways. See, e.g., CAL. Welf. \& Inst'Ns CODE $\S \S 1300-08$ (West 1972) (Interstate Compact on Juveniles). Moreover, the general supervision provisions of many of those laws apply to runaways as well. See, e.g., id. $\S 601$.

49. See, e.g., Roe v. Doe, 29 N.Y.2d 188, 272 N.E.2d 567, 324 N.Y.S.2d 71 (1971).

50. D. Reisman, The Lonely Crowd 9 (1960) characterizes as "other directed" those who look to external clues, to what others expect of them in the governance of their own lives. It is suggested here that those who have experienced prolonged childhood have received a particularly virulent strain of "other directedness." 
myth, but at the same time, they more actively denied autonomy to their own children. Erikson has observed: $:^{51}$

Where large numbers of people have been prepared in childhood to expect from life a high degree of personal autonomy, pride, and opportunity, and then in later life find themselves ruled by impersonal organizations and machineries too intricate to understand, the result may be deep chronic disappointment that makes them unwilling to grant each other-or their children-a measure of autonomy.

The youth of the 1960's, however, began to question some of the assumptions underlying the system that raised them and to assert, directly and indirectly, a new autonomy vis-a-vis not only the family, but its supporting social and political institutions as well. Their changing styles of political debate and life in general set them apart from their parents. In Tinker $v$. Des Moines Independent Community School ${ }^{52}$ the United States Supreme Court invested this asserted autonomy with greater substance by declaring that high school students have a constitutional right of free expression. And in Buckholz v. Leveille, ${ }^{53}$ the Michigan Court of Appeals brought the matter down to a more mundane level. Plaintiff, a sixteen-year-old student, was expelled from high school because his long hair did not conform with the official dress code. He brought action against the school through his attorney, a legal service lawyer who was appointed guardian ad litem, seeking reinstatement. His parents, who supported the school authorities in the matter, were opposed to the law suit. On the basis of the parents' representation, the trial court dismissed the complaint "since ... the school board is merely doing, with the parents' consent, that which the parents could do."54 The appellate court disagreed, however, holding that parental opposition to the suit was irrelevant because, under Michigan law, the son had juristic standing to bring the action in his own name after he was fourteen years old.

Buckholz did not directly rule on the son's autonomy vis-a-vis his parents, and presumably they could punish him for his disobedience in not getting his hair cut or refusing to drop the law suit when they expressed disapproval. The case does, however, stand for the proposition that parental authority does not limit a sixteen-year-old's autonomy in his relations with the community at large. And in this sense, the case diminishes-albeit indirectly-parental authority and correspondingly enhances the adolescent's status within the family.

Buckholz, recognizing dissonance among parents and children, parallels the passing of another legal rule as well that was said in the past to rest on con-

51. E. ERIKSON, supra note 10 , at 114.

52. 393 U.S. 503 (1969).

53. 37 Mich. App. 166, 194 N.W.2d 427 (1972).

54. Id. at 429 . 
siderations of parental authority and family harmony-namely, the rule that a parent is immune from a personal tort action brought by an unemancipated child. ${ }^{55}$ Always viewed as curious by American commentators, ${ }^{56}$ this rule, as initially articulated, was held to apply to both negligent and intentional torts. ${ }^{\mathbf{7}}$ Intentional torts, however, have now universally been excluded from coverage,${ }^{58}$ and marked erosion of the rule can be discerned even in simple negligence cases. ${ }^{59}$

Medical emancipation laws and cases signal an even more direct governmental approach to social problems that may be attributable to inflexible community support of parental authority. Historically, unemancipated minors could not receive medical treatment without parental consent. One way of coping with the rising incidence of adolescent venereal disease, pregnancy, and drug use in the mid-1960's, therefore, would have been to regard such matters as primarily within the purview of parental responsibility and authority. This approach would not, however, necessarily have effected a change in the particular kind of adolescent behavior involved-indeed, there was ample evidence that such "unacceptable" behavior might, in fact, have been an overreaction to excessive parental control, a thinly-veiled assertion of independence. Some legislatures wisely have seemed to recognize this and to have responded by conferring on minors the legal capacity independently to seek and arrange for appropriate medical attention to these problems. ${ }^{60}$

These medical emancipation laws are a significant development, in that they explicity permit the adolescent to assume responsibility for his own actions in other than narrowly-confined social situations and problems. In some states, the approach is rather tentative. Thus, in Michigan, doctors are allowed to communicate with parents in cases involving venereal disease. This no doubt reflects a residual legislative ambivalence in the matter. In other

55. See Hewellette v. George, 68 Misc. 703, 9 So. 885 (189l). This rule has since widely been followed in other jurisdictions. See W. Prosser, supra note 5, at 865 . But cf. J. Fleming, supra note 5 , at $644-45$.

56. See, e.g., W. Prosser, supra note 5 , at 865.

57. See, e.g., Roller v. Roller, 37 Wash. 242,79 P. 788 (1905), in which it was held that a daughter had no common law cause of action against her father for rape.

58. See, e.g., Cogwill v. Bock, 189 Ore. 282, 218 P.2d 445 (1950).

59. See generally Child v. Parent: Erosion of the Immunity Rule, 19 HAsT. L.J. 201 (1967).

60. For venereal disease, sce, e.g., Cal. Civ. Code $\$ 34.7$ (West Supp. 1975) (twelve years old and over); Мıсн. Comp. Laws Ann. $\$ 329.221$ (1975) (no minimum age stated); N.M. Stat. Ann. $\S 12-34-9$ (Supp. 1973) ("regardless of age"). Presumably puberty describes a biological minimum age before which the problems of venereal disease control are inconsequential. For drug addiction, see, e.g., Ill. Anv. Stat. ch. 91, § 18.4 (Smith-Hurd Cum. Supp. 1975) (twelve years old and over). For pregnancy, see, e.g., Cal. Civ. Code $\$ 34.5$ (West 1954) (no minimum age stated); N.M. Stat. AnN. § 12-34-13 (Supp. 1973) ("regardless of age"). See also In re Smith, 16 Md. App. 209, 295 A.2d 238 (1972) (parents may not direct involuntary abortion); Coe v. Gerstein, 376 F. Supp. 695 (S.D. Fla. 1973) (parental consent not required for abortion, even absent medical emancipation law); Ballard v. Anderson, 4 Cal. 3d 873, 484 P.2d 1345, 95 Cal. Rptr. I (1971) (parental consent not required for therapeutic abortion). 
states, however, no such reservations are evident. Thus, for example, in Mississippi, unemancipated minors who are "of sufficient intelligence to understand and appreciate consequences" of medical and surgical treatment may contract for such services fully without parental consent. ${ }^{61}$ This is a natural extension of the rationale underlying the concept of "informed consent." 62 It is still, however, too early to tell whether such medical emancipation signals a more generalized erosion of the legal underpinnings of parental authority and control.

\section{Conclusion}

The fundamental issue here examined-enforced prolongation of childhood status-goes deeper than the dislocation of the individual adolescent caught between his desires and fabric of parental and social controls. A crisis of institutions appears also to be involved. What had once been regarded as a time of tentative groping for self-identity, with room for failure or success on the adolescent's own terms, has become a time for preparation on someone else's terms. And the idealized family, schools, and a benevolent juvenile protective and justice system, tailored to implement this purpose-presumably for the benefit of the adolescent-have come more to resemble elements of social planning than warm and natural institutions of socialization.

The events of the 1960's and 1970's have caused many seriously to reflect about these institutions. Thus, a recent report of the National Commission on the Reform of Secondary Education has recommended lowering the age of compulsory education to fourteen years. ${ }^{63}$ And the Juvenile Justice and Delinquency Act of 1974, taking note of the huge dimensions of the runaway problem, has funded states to find innovative alternative institutions to the family and the juvenile court system for supporting an earlier quest for independence. ${ }^{64}$

A radical rethinking in other areas is indicated as well. The beneficiaries may be not only our children, but us. At a time when parents who have experienced the protracted childhood of the twentieth century have become accustomed to more and more choices being made for them-as adults-by the state, a reexamination of basic premises may prove illuminating. In the last analysis, the choices we allow our children to make may affect the choices we allow ourselves to make.

61. Miss. CoDE ANv. § 41-41-3(h) (1972).

62. See generally Comment, Restructuring Informed Consent: Legal Therapy for the Doctor-Patient Relationship, 79 YALE L.J. 1533 (1970).

63. National Commission on the Reform of Secondary Education, The Reform of Secondary Education 21 (1973).

64. Juvenile Justice and Delinquency Prevention Act of 1974, 88 Stat. 1109 (codified in 5 U.S.C. $\S 5108$, and scattered sections of 18,42 U.S.C.). 